\title{
SOIL ATTRIBUTES UNDER DIFFERENT WATER MANAGEMENT SYSTEMS OF RICE PADDIES IN THE AMAZONIAN SAVANNA OF BRAZIL ${ }^{1}$
}

\author{
ARIANE EVALD ${ }^{2}$, VALDINAR FERREIRA MELO ${ }^{3 *}$, PAULO ROBERTO RIBEIRO ROCHA ${ }^{3}$, ANTÔNIO \\ CARLOS CENTENO CORDEIRO ${ }^{4}$, SONICLEY DA SILVA MAIA ${ }^{5}$, ITHALO DE CASTRO ESPINDOLA ${ }^{5}$
}

\begin{abstract}
The rational use of water while considering the increases in food production is a great challenge for agriculture currently. The aim of the present study was to evaluate the soil properties of rice paddy areas under different water management systems. For this, the rice cultivars BRS Tropical and IRGA 424 were grown under the following treatments: M1: Intermittent flooding; M2: Intermittent flooding, followed by continuous flooding; M3: Continuous flooding, followed by intermittent flooding; and M4: Continuous flooding for the entire plant cycle. As a control, a non-cultivated area, adjacent to the experimental plots was also evaluated. The variables analyzed were $\mathrm{P}, \mathrm{K}^{+}, \mathrm{Ca}^{2+}, \mathrm{Mg}^{2+}$ and $\mathrm{Al}^{3+}$ contents, $\mathrm{pH}$, soil organic carbon (SOC), total nitrogen (TN) Carbon Stock (C-Stock), nitrogen stock (N-Stock), Cation-exchange capacity (CEC), $\mathrm{C} / \mathrm{N}$ ratio; $\mathrm{CO}_{2}$ emission, soil microbial biomass carbon (SMB), metabolic coefficient ( $q$ Mic) and acid phosphatase and urease activities. There was not difference among the different water management systems for $\mathrm{P}, \mathrm{K}^{+}, \mathrm{Mg}^{2+}, \mathrm{CEC}$ and $\mathrm{C} / \mathrm{N}$ ratio. The SMB and the acid phosphatase and urease activities were lower under the different treatments when compared to the control. The $\mathrm{CO}_{2}$ emission under rice paddy system was influenced by the phenological phase of the crop. The variables SOC, C-Stock, SMB, C/N ratio, $\mathrm{K}^{+}$, acid phosphatase and usease activities are those most sensitive attributes observed in the soil under different water management systems during rice cultivation. Water management in the rice paddy system influenced soil by changing its quality.
\end{abstract}

Keywords: $\mathrm{CO}_{2}$ efflux. Paddy environment. Soil enzymes. Soil quality indicators.

\section{ATRIBUTOS DO SOLO SOB DIFERENTES SISTEMAS DE MANEJO DA ÁGUA EM SOLO CULTIVADO COM ARROZ, NA SAVANA AMAZÔNICA, BRASIL}

\begin{abstract}
RESUMO - O uso racional da água na produção de alimentos é um desafio no cenário atual. Objetivou-se no presente estudo avaliar as características do solo em área de arroz irrigado sob diferentes sistemas de manejo da água. Para isso, avaliou-se os sistemas de manejos de irrigação do arroz: M1- Inundação intermitente; M2Inundação intermitente na fase vegetativa até $50 \%$ de floração média, seguida de inundação contínua até a maturação; M3- Inundação contínua na fase vegetativa até $50 \%$ de floração, seguida de inundação intermitente até a maturação e M4- Inundação contínua durante todo o ciclo e duas cultivares BRS Tropical e IRGA 424. Como controle, uma área não cultivada, também foi avaliada. Avaliou-se os teores de $\mathrm{P}, \mathrm{K}^{+}, \mathrm{Ca}^{2+}, \mathrm{Mg}^{2+}, \mathrm{Al}^{3+} \mathrm{e}$ $\mathrm{H}+\mathrm{Al}$, pH, carbono orgânico do solo (COS), nitrogênio total, estoque de carbono, estoque de nitrogênio, capacidade de troca catiônica, relação $\mathrm{C} / \mathrm{N}$; Emissão de $\mathrm{CO}_{2}$, carbono da biomassa microbiana do solo (CBMS), coeficiente metabólico (qMic) e atividades da fosfatase e da urease. Não houve diferença entre os sistemas de manejo de água quanto aos atributos $\mathrm{P}, \mathrm{K}^{+}$e $\mathrm{Mg}^{2+}$, CTC e relação C/N. O CBMS, as atividades da fosfatase e urease foram mais baixas em todos tratamentos quando comparados ao controle. A emissão de $\mathrm{CO}_{2}$ foi influenciada pela fase fenológica da cultura. O COS, estoque de carbono, CBMS, relação $\mathrm{C} / \mathrm{N}, \mathrm{K}^{+} \mathrm{e}$ atividades da fosfatase foram os atributos mais sensíveis nos diferentes sistemas $\mathrm{O}$ manejo da água influencia as propriedades do solo, alterando sua qualidade.
\end{abstract}

Palavras-chave: Efluxo de $\mathrm{CO}_{2}$. Arroz inundado. Enzimas do solo. Indicadores de qualidade do solo.

\footnotetext{
*Corresponding author

${ }^{1}$ Received for publication in 04/16/2020; accepted in 04/20/2021.

Extracted from the first author's masters dissertation.

${ }^{2}$ Graduate Program in Agronomy, Universidade Federal de Roraima, Boa Vista, RR, Brazil; arianeevald@gmail.com - ORCID: 0000-0003$1676-8498$

${ }^{3}$ Department of Soil and Agricultural Engineering, Universidade Federal de Roraima, Boa Vista, RR, Brazil; valdinar@yahoo.com.br ORCID: 0000-0002-7943-9969, paulo.rocha@ufrr.br-ORCID: 0000-0003-4848-385X

${ }^{4}$ Embrapa Roraima, Boa Vista, RR, Brazil; antonio.cordeiro@embrapa.br - ORCID: 0000-0002-8197-2439.

${ }^{5}$ Undergraduate Course of Agronomy, Boa Vista, RR, Brazil; sony_maia@hotmail.com- ORCID: 0000-0003-0167-3218, ithaloespindola@hotmail.com - ORCID: 0000-0003-1951-2551
} 


\section{INTRODUCTION}

One of the challenges that the agriculture in the 21 st century encounters is to increase food production at lower cost per area unit with reduced labor and the need for sustainable use of water resources (UPHOFF, 2012). In the modern agriculture, the search for more sustainable practices has largely been based on reducing water use (XU et al., 2015; PEYRON et al., 2016). In this scenario, intermittent irrigation has become increasingly popular, as the system provides higher crop yield levels by continuous irrigation, but under extensive water, savings during the growing cycle of rice (PEYRON et al., 2016).

In Brazil, although rice is produced under a variety of different cropping systems and soil types, the paddy system is becoming the most common. The Roraima state has a natural floodplain area around 160,000 ha, and this natural condition favor greatly the paddy system in a large scale compared to other Brazilian states (BARBERENA; MEDEIROS; BARBOSA, 2011).

In the paddy system, the flooding results in changes to the chemical, physical and biological aspects of the soil. Consequently, a chemical reduction promoted by bacterial anaerobic respiration resulted in organic matter oxidation, which led to lower $\mathrm{O}_{2}$ levels and a significant alteration in the redox potential (TIAN et al., 2013; MARRENJO et al., 2016). Such changes alter the elements availability in their stable forms reducing the soil fertility in paddy areas (KÖGEL-KNABNER et al., 2010; SCHMIDT et al., 2013).

A study carried out in China on soil carbon assimilation in a rice growing area, Tian et al. (2013) concluded that under different water management systems that influenced the soil carbon sequestration mechanism, more assimilated $\mathrm{C}$ remained in shoots and roots under continuously flooded treatment. Biological attributes are also altered by the transition from aerobic to anaerobic environment, resulting in a reduction of microbial diversity (MENDES et al., 2012). Such results highlight the importance of studying the impacts of different water management systems during rice production to understand the chemical, physical and biological processes, considering the volume of rice production and the dimension that this activity represents globally.

Research conducted in Brazil about soil quality indicators in rice crop has been developed mainly at the south region. By Lima, Hoogmoed, Brussaard (2008) and Lima et al. (2013) attempted to identify viable indicators for soil quality. The authors analyzed soil organic matter and the abundance and diversity of earthworms which were shown to be sensitive indicators of soil quality. In addition, they also analyzed total nitrogen, cation exchange capacity (CEC), microbial biomass carbon, and the alkaline and acid phosphatase and $\beta$-glucosidase enzyme activities.

Agriculture contributes significantly to the greenhouse gases emission (PEYRON et al., 2016). For this reason, there is a need to understand how the emission process occurs under different crop management systems. There are few studies related to the greenhouse gases (GHG) under different water management in a rice paddy system. Testing different water management system (continuous irrigation, flooding and intermittent wet irrigation and intermittent flooded and dry irrigation) and different cultivars, $\mathrm{Xu}$ et al. (2015) observed that continuous irrigation resulted in the lowest $\mathrm{CO}_{2}$ efflux.

In a rice paddy system, the hypothesis discussed in the literature is that the different water managements affect the soil $\mathrm{CO}_{2}$ emission, and physical, chemical, and biological soil attributes. The aim of the present study was to evaluate the soil quality indicators most sensitive to changes in rice paddies on floodplain soil and submitted to different water management systems.

\section{MATERIAL AND METHODS}

The experiments were carried out in a floodplain area (EMBRAPA - RR) located at Santa Cecília Farm, Cantá municipality - RR from December 2014 to April 2015 crop season (Figure $1)$. The regional climate is tropical rainy (KöppenGeiger type Aw) with average annual precipitation of $1600 \mathrm{~mm}$ and average temperature of $27.4{ }^{\circ} \mathrm{C}$. The study area has been the site of rice experiments since 2010.

The soil in the area is classified as Dystric Gleysol (WRB) and Typic Fluvaquent (US Soil Taxonomy), formed from Holocente fluvial terrace sediments. Before planting, chemical and physical attributes of soil layer ( 0.00 to $0.20 \mathrm{~m}$ depth) were analyzed with the following results: $\mathrm{pH}$ in $\mathrm{H}_{2} \mathrm{O}-4.9$; OC $-7.48 \mathrm{~g} \mathrm{~kg}^{-1} ; \quad \mathrm{P} \quad-10.14 \mathrm{mg} \mathrm{dm}^{-3} ; \mathrm{K}^{+}$ - $43.00 \mathrm{mg} \mathrm{dm}{ }^{-3} ; \mathrm{Ca}^{2+}-0.58 \mathrm{cmol}_{\mathrm{c}} \mathrm{dm}^{-3} ; \mathrm{Mg}^{2+}$ - $0.27 \mathrm{cmol}_{\mathrm{c}} \mathrm{dm}^{-3} ; \mathrm{Al}^{3+}$ - $1.11 \mathrm{cmol}_{\mathrm{c}} \mathrm{dm}^{-3} ; \mathrm{SB}$ - 0.95 cmol $_{c}$; effective CEC - 2.06; V - 46\%; m - 54\% clay - $340 \mathrm{~g} \mathrm{~kg}^{-1}$; silt - $410 \mathrm{~g} \mathrm{~kg}^{-1}$ and sand $-250 \mathrm{~g} \mathrm{~kg}^{-1}$.

The experiments were set up in bands in a randomized block design with, four replications. The treatments consisted of a combination of four water irrigation systems and two rice cultivars. The irrigation management systems evaluated were: M1Intermittent flooding, M2 - Intermittent flooding in vegetative phase (up to $50 \%$ average flowering), followed by continuous flooding until maturation ( $90 \%$ of mature panicles), M3 - Continuous flooding 
in vegetative phase (up to $50 \%$ flowering), followed by intermittent flooding until maturation, and M4 Continuous flooding throughout the cycle. In the plots, within each band, the replications with the cultivars. The rice cultivars used were BRS Tropical (C1) and IRGA 424 (C2). An uncultivated area (native vegetation), adjacent to the experimental plots, were used as a control.

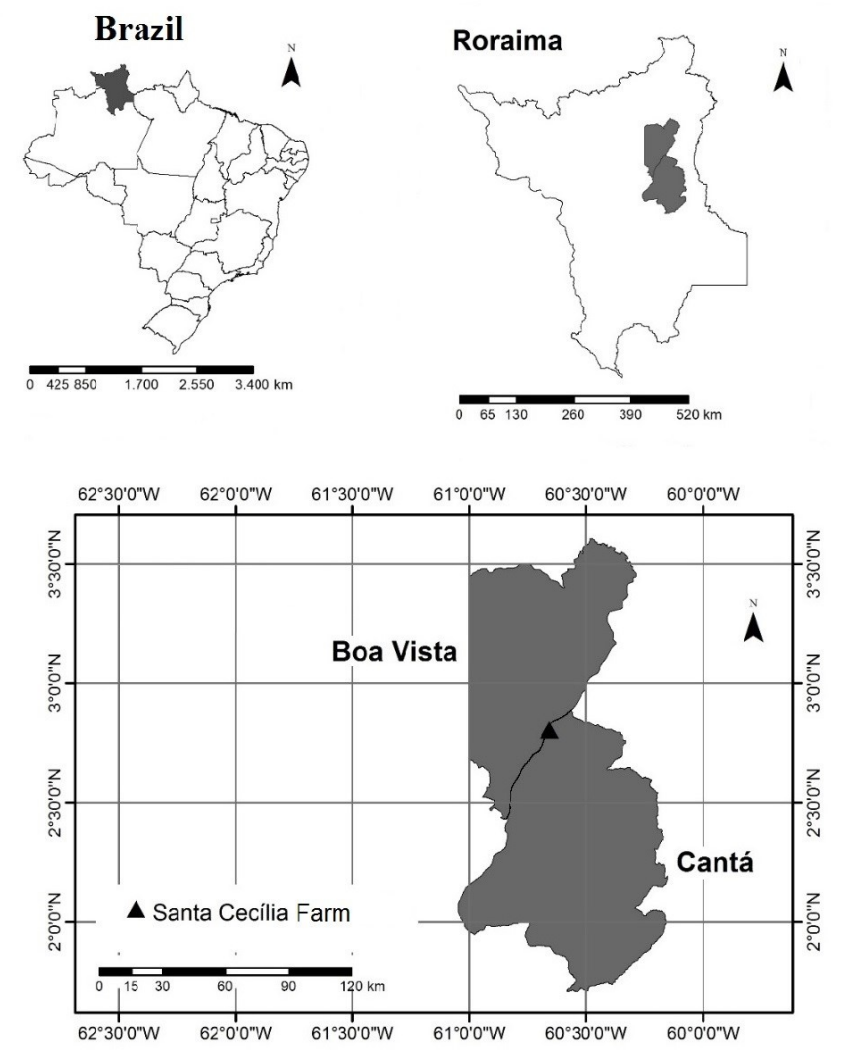

Figure 1. Location where the experiments were settled.

The experimental areas were prepared using standard disc plough and tillage implements with one plowing and two harrowings at $0.20 \mathrm{~m}$ depth, 30 days before sowing to leveling the terrain and construct the bunds (or dikes). In addition, the soil was limed with $1.2 \mathrm{t} \mathrm{ha}^{-1}$ of dolomitic limestone after correction of PRNT $85 \%$ (Relative Power of Total Neutralization) based on the above soil chemical results.

The plots $(20 \times 7 \mathrm{~m})$ were separated by bunds. The rice seeds were sowed directly into planting lines (100 seeds $\left.\mathrm{m}^{-1}\right)$, before flooding, on drained soil. Each plot contained seven lines with $5 \mathrm{~m}$ of length, spaced $0.20 \mathrm{~m}$ apart.

The plots were fertilized by the application of $450 \mathrm{~kg} \mathrm{ha}{ }^{-1}$ NPK formulation (08-28-16), a micronutrients mix $(2.25 \mathrm{~kg} \mathrm{Zn}, 0.45 \mathrm{~kg} \mathrm{~B}$, $0.9 \mathrm{~kg} \mathrm{Mn}$ per ha) and two spreadings of $150 \mathrm{~kg} \mathrm{ha}^{-1}$ urea at 15 and 45 days after roots emergence (DAE). The irrigation started at $23 \mathrm{DAE}$ when plants reached the V4 stage (4 leaves). The water depth, in each plot, was maintained at $0.05 \mathrm{~m}$ height (continuous flooding), or irrigation every two days during 100 days (intermittent inundation).

After harvesting, three sub-samples of soil were collected from $0.00-0.10 \mathrm{~m}$ soil layer depth in each plot, combined to provide a composite plot sample, with four replicates per treatment. An adjacent uncultivated area provided a control and was subdivided into four blocks $(10 \times 10 \mathrm{~m})$, with three samples per block to provide a composite sample.

Soil samples were divided into two small samples: one for chemical and one for microbiological and biochemical analysis. For chemical analyses, thin air-dried soil samples (TADS) were prepared, passed through a $2 \mathrm{~mm}$ mesh sieve and stored in plastic bags until further analysis. The samples collected for microbiological and biochemical analysis were sieved with a $2 \mathrm{~mm}$ mesh sieve, and stored under refrigeration $\left(4\right.$ to $\left.7^{\circ} \mathrm{C}\right)$ until further analysis. For the microbiological and biochemical essays, the samples were prepared shortly before analysis via sieving through a $2 \mathrm{~mm}$ mesh sieve and the vegetal fragments manually removed.

Chemical attributes analyzed: soil organic carbon (SOC) by oxidation with potassium dichromate using the Walkley-Black method; total nitrogen (TN) by sulphuric acid digestion; $\mathrm{Ca}^{2+}$ and 
$\mathrm{Mg}^{2+}$ extracted with $\mathrm{KCl} 1 \mathrm{~mol} \mathrm{~L}^{-1}$ determined by atomic absorption spectrophotometry (SILVA, 2009); $\mathrm{P}$ and $\mathrm{K}$ were extracted by the double-acid solution $\left(\mathrm{HCl} 0,05 \mathrm{M}+\mathrm{H}_{2} \mathrm{SO}_{4} 0,0125 \mathrm{M}\right.$ ), and determined by UV-Visible spectrophotometry and flame photometry, respectively; $\mathrm{Al}^{3+}+\mathrm{H}^{+}$ exchangeable extracted with calcium acetate; $\mathrm{Al}^{3+}$ extracted by $\mathrm{KCl} 1 \mathrm{~mol} \mathrm{~L}^{-1}$; $\mathrm{pH}\left(\mathrm{H}_{2} \mathrm{O}\right)(1: 2.5)$; SOC stock (SOCs) was calculated from the carbon content multiplied by the soil bulk density at $0.10 \mathrm{~m}$ depth; $\mathrm{N}$ stock (Ns) was calculated based on the $\mathrm{N}$ content multiplied by the soil bulk density at $0.10 \mathrm{~m}$ depth

Microbiological attributes assessed: microbial biomass carbon (SMB-C) by a fumigation and extraction method (TATE et al., 1988); soil basal respiration (SBR) via evolved $\mathrm{CO}_{2}$ extracted with NaOH (JENKINSON; POWLSON, 1976); metabolic quotient $\left(q \mathrm{CO}_{2}\right)$ was calculated as the ratio SBR and; microbial coefficient $(q \mathrm{Mic})$ was calculated as the ratio between SBM-C and SOC. Acid phosphatase was determined by $p$-nitrophenol phosphate release (TABATABAI, 1994) and urease was determined by the salicylate method (KANDELER; GERBER, 1988), with both measurements being carried out by UV-Visible Spectrophotometer FEMTO.

Soil bulk density was determined by volumetric ring texture using the pipet method with Wagner's stirrer (SILVA, 2009). Soil bulk density was used to calculate soil carbon stock.

Throughout the crop cycle, $\mathrm{CO}_{2}$ flow measurements were made with the automatic $\mathrm{CO}_{2}$ measurement system (LI-COR $8100 \mathrm{~A}$ ), set on 0.10 $\mathrm{m}$ diameter PVC tubes at $0.20 \mathrm{~m}$ height $(0.04 \mathrm{~m})$ inserted into the soil and $0.16 \mathrm{~m}$ being above the surface. Each plot of the irrigation systems and rice cultivars used had two tubes, located between the third and fourth rows. The measurement of $\mathrm{CO}_{2}$ flow started 15 days after tube installation (23 DAE) and were taken in intervals of 15 days each (seven readings). The readings of $\mathrm{CO}_{2}$ efflux were also sampled in the control plot $(10 \mathrm{~m}$ distance between the tubes) with four replications. During sampling at the water management plots, soil temperature and humidity were also measured. The humidity in the permanently inundated experimental area was considered as $100 \%$ since the soil was always saturated.

Data were tested by analysis of variance using F test $(p \leq 0.05)$ and, when significant, the averages were compared using a Tukey test $(p \leq 0.05)$ by Sisvar Software version 5.6 (FERREIRA, 2014). The control data was analyzed by non-parametric Kruskal Wallis test $(p \leq 0.05)$ by Info-Gen program (DI RIENZO et al., 2013). Canonical analysis of all studied variables were performed. The data set was reduced in linear combinations, generating scores or the first two canonical variables, which explain more than $80 \%$ of the total variation (CRUZ; REGAZZI, 1994). To determine which water management systems were most similar, Tocher Grouping Analysis was performed by the Info-Gene version 2012 program (DI RIENZO et al., 2013). For $\mathrm{CO}_{2}$ efflux, adjusted regression models were used to the biological response, regression coefficient significance and determination coefficients by Sigmaplot program 11 (Systat Software).

\section{RESULTS AND DISCUSSION}

There were no significant statistical interaction between the irrigation systems and the studied cultivars for the evaluated chemical variables. There was no statistical difference between water management systems regarding the variables $\mathrm{TN}, \mathrm{P}, \mathrm{K}^{+}, \mathrm{Mg}^{2+}, \mathrm{Al}^{3+}, \mathrm{H}^{+}, \mathrm{pH}$ and $\mathrm{C} / \mathrm{N}$ ratio (Table 1). When comparing the growing areas with the control, $\mathrm{Mg}^{2+}$, ECEC and $\mathrm{C} / \mathrm{N}$ ratio also showed no statistical differences.

Table 1. Chemical quality indicators in Dystric Gleysol rice paddies under different water management systems.

\begin{tabular}{|c|c|c|c|c|c|c|c|c|c|c|c|}
\hline \multirow{3}{*}{ Treatments } & \multicolumn{11}{|c|}{ Variables } \\
\hline & SOC & $\mathrm{TN}$ & $\mathrm{P}$ & $\mathrm{K}^{+}$ & $\mathrm{Ca}^{2+}$ & $\mathrm{Mg}^{2+}$ & $\mathrm{Al}^{+3}$ & $\mathrm{H}^{+}$ & ECEC & $\mathrm{pH}$ & $\mathrm{C} / \mathrm{N}$ \\
\hline & \multicolumn{2}{|c|}{ 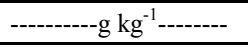 } & \multicolumn{2}{|c|}{$\mathrm{mg} \mathrm{kg}^{-1}$ soil } & \multicolumn{5}{|c|}{ 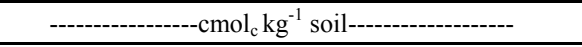 } & $\mathrm{H}_{2} \mathrm{O}$ & -- \\
\hline M1 & $4.1 b^{*}$ & $0.25 \mathrm{~b}^{*}$ & $39 *$ & $44^{*}$ & $0.60 a^{*}$ & 0.25 & $0.91 \mathrm{ab}^{*}$ & $2.82 *$ & 1.88 & $4.8 b^{*}$ & 16 \\
\hline M2 & $3.9 b^{*}$ & $0.27 a b^{*}$ & $45^{*}$ & $33 *$ & $0.52 b^{*}$ & 0.23 & $1.10 \mathrm{ab}$ & $2.63 *$ & 1.88 & $4.7 b^{*}$ & 14 \\
\hline M3 & $4.4 \mathrm{ab}^{*}$ & $0.29 \mathrm{ab}$ & $37 *$ & $38 *$ & $0.65 \mathrm{a}^{*}$ & 0.25 & $0.63 \mathrm{a}^{*}$ & $2.61 *$ & 1.62 & $5.0 \mathrm{a}$ & 15 \\
\hline M4 & $4.5 \mathrm{a}$ & $0.30 \mathrm{a}$ & $48^{*}$ & $42 *$ & $0.76 \mathrm{a}^{*}$ & 0.29 & $0.92 \mathrm{ab}^{*}$ & 2.97 & 2.08 & $4.7 b^{*}$ & 15 \\
\hline Mean & 4.2 & 0.28 & $42 *$ & $39 *$ & 0.62 & 0.26 & 0.89 & 2.76 & 1.87 & 4.8 & 15 \\
\hline CV\% ${ }^{1}$ & 9.5 & 9.64 & 29 & 40 & 36.95 & 25.46 & 26.58 & 13.89 & 24.4 & 2.93 & 15 \\
\hline $\begin{array}{c}\text { MSD } \\
\text { (Tukey) }\end{array}$ & 0.62 & 0.042 & - & - & - & - & 0.37 & - & - & 0.22 & 15 \\
\hline Control & 8.1 & 0.32 & 5.08 & 80 & 0.42 & 0.21 & 1.41 & 4.19 & 2.34 & 5.20 & 26 \\
\hline
\end{tabular}

Treatments: M1: Intermittent during entire cycle; M2: Intermittent/continuous; M3: Continuous/intermittent and M4: Continuous for entire cycle. The means followed by the same lowercase letter in the column do not differ statistically by Tukey test $(p \leq 0.05)$; MSD: Minimum significant difference between water managements, using the Tukey test. The means followed by an asterisk $\left(^{*}\right)$ differ significantly from the control by Kruskal Wallis test $(p \leq 0.05)$. ${ }^{1} \mathrm{CV} \%$ - Coefficient of variation. 
Water treatments M3 and M4 showed the greatest SOC accumulation (Table 1). Under continuous irrigation (M4) resulted in anoxic soil conditions throughout the crop cycle, reducing soil organic matter (OM) oxidation. In saturated soils, OM decomposition occurs at lower rates, because of the lower $\mathrm{O}_{2}$ concentrations. In the absence of $\mathrm{O}_{2}$, anaerobic microorganisms use other ions, such as $\mathrm{Fe}^{2+}, \mathrm{Mn}^{2+}$ and sulphate as electron acceptors, resulting in the partial oxidation of organic C (TIAN et al. 2013).

The TN values varied between treatments, where the M4 treatment resulted in the highest accumulation $\left(0.3 \mathrm{~g} \mathrm{~kg}^{-1}\right)$ of TN in the soil (Table 1$)$. This result is correlated to the higher SOC contents under this treatment (Table 1). As can be observed in Table 1, the TN values differed from the control only for M1 and M2 water management treatments $(0.25$ and $0.27 \mathrm{~g} \mathrm{~kg}^{-1}$, respectively). Also, the M1 and M2 treatments had the lowest SOC values (4.02 and $3.86 \mathrm{~g} \mathrm{~kg}^{-1}$, respectively) when compared to the control area.

The relationship between SOC content and the decrease in soil NT content during inundation is associated to $\mathrm{N}$ mineralization in the soil (SLEUTEL et al., 2008). This increase started early during flooding and at the end of the crop cycle, which results in a lower TN content in growing soil. The present results corroborate with the findings by Rhoden et al. (2006) that studied N mineralization in flooded soils under rice cultivation and observed a higher rate of $\mathrm{N}$ mineralization in the first 15 days of flooding. These authors compared mineralization based on the TN levels and SOM, finding a positive correlation between these two variables; they concluded that it is possible to estimate $\mathrm{N}$ availability indexes for flooded rice growing areas.

In this context, as compared to the control, we can support the hypothesis that the TN reduction in water management systems is related to the decrease of SOC, mineralization of N (Table 1). Studying rice production in a Gleysol (FAGERIA; SANTOS, 2007) found that $\mathrm{K}^{+}$levels under continuous flooding was significantly higher in the sub-surface layers than those under an intermittent flooding regimen in the vegetative and maturation stages. According to these authors, there is potassium distribution in the soil profile up to $0.80 \mathrm{~m}$ depth, due to element lixiviation through the profile. However, under an intermittent/continuous flooding regime a zone of $\mathrm{K}^{+}$ concentration is observed in a layer at $0.20-0.40 \mathrm{~m}$ depth. Another factor that could be related to lower $\mathrm{K}^{+}$value during flooding is the greater availability of this nutrient in soil solution, which may enhance the capacity of the plants to absorb this nutrient, leading to its increased removal from the soil.

The $\mathrm{Ca}^{2+}$ content reached the most significant difference between samples from the rice cultivation areas compared to the control one (Table 1). The higher $\mathrm{Ca}^{2+}$ levels observed on soil under different water managements is expected and it is explained due to the limestone application before planting.

As shown in Table 1, there was a difference between treatments regarding $\mathrm{pH}$ values. The highest values (5.0) were detected only for the M3 treatment. The $\mathrm{pH}$ value for the control treatment were only higher when compared to M1, M2 and M4 treatments (Table 1). Although there were statistical differences among treatments and control, it is observed that all treatments have strong to medium acidity. This acidity can be explained by fact of samples were collected after soil drainage, which reverses the reduction to oxidation process of soil. In addition, it was observed that the dose of limestone was not enough to improve the levels of $\mathrm{Ca}^{2+}$ and $\mathrm{Mg}^{2+}$, important to increase base saturation up to $50 \%$, which is the minimum for rice cultivation according to Ferreira et al. (2009). According to Knoblauch et al. (2014), in most cases, soil-flooding causes increased in $\mathrm{pH}$, which can reach values around 6.0, and can remain stable up to 30 days after flooding. In the present study, the soil sampling were assessed 20 days after irrigation suspension, during drainage, and the soil moisture was below 30\%. For this reason, the observed $\mathrm{pH}$ differences between the water management areas compared to the control can be explained. During the soil drainage process, $\mathrm{O}_{2}$ enters the system, oxidizing $\mathrm{Fe}^{2+}$, releasing $\mathrm{H}^{+}$by water hydrolysis, decreasing the soil $\mathrm{pH}$ (WEIL; BRADY, 2016).

There was no interaction between water management systems and the cultivars for the biological attributes studied (Table 2). There was no significant statistical difference in $\mathrm{MBC}$ between the water management systems studied. However, all treatments had lower MBC values when compared to the control, where the water management negatively impacted the $\mathrm{MBC}$ values. The highest values found to the control samples can be attributed to the intermittent conditions, which may favored a greater diversity and abundance of microorganisms (MENDES et al., 2012).

There were no significant statistical difference between the treatments when compared to the control regarding $q \mathrm{Mic}$ values (Table 2). The $q$ Mic values found for all treatments were considered normal. The anaerobic condition during rice cultivation under flooding influences the diversity and quantity of soil microorganisms, as well as their efficiency. According to Mendes et al. (2012), the anaerobic environments reduce the diversity and quantity of microorganisms when compared to aerobic conditions. 
A. EVALD et al.

Table 2. Microbial biomass carbon (MBC) and metabolic coefficient ( $q$ Mic) values in a Dystric Gleysol rice paddies with different water management systems.

\begin{tabular}{ccc}
\hline & \multicolumn{2}{c}{ Variables } \\
\cline { 2 - 3 } Treatments & $\begin{array}{c}\text { MBC } \\
\mathrm{mg} \mathrm{C} \mathrm{kg}^{-1} \text { soil }\end{array}$ & $\begin{array}{c}q \text { Mic } \\
(\%)\end{array}$ \\
\hline M1 & $139.03 *$ & 3.45 \\
M2 & $108.72^{*}$ & 2.81 \\
M3 & $117.00^{*}$ & 2.67 \\
M4 & $142.4 *$ & 3.18 \\
Mean & 126.79 & 3.38 \\
\hline CV\% & 28.85 & 32.06 \\
\hline Control & 271.61 & 1.24 \\
\hline
\end{tabular}

M1: Intermittent during entire cycle; M2: Intermittent/continuous; M3: Continuous/intermittent and M4: continuous for entire cycle. Means followed by an asterisk $\left.{ }^{*}\right)$ differ significantly from native vegetation by Kruskal Wallis test $(p<0.05)$.

The acid phosphatase activity statistically differed among M1 and M3 treatments (Table 3). The highest enzymatic activity was observed on M3 treatment. As compared to the control, only M3 did not differ statistically, with all other samples showing decreases in acid phosphatase activity. This result is linked to SOC values, in which higher concentrations leads to a higher phosphatase activity. Mendes et al. (2012) reported a positive correlation between organic carbon content and acid phosphatase activity under natural savanna conditions. M3 was the treatment that demonstrated the lowest available $\mathrm{P}\left(36.76 \mathrm{mg} \mathrm{kg}^{-1}\right)$, and one of the highest SOC levels $\left(4.37 \mathrm{~g} \mathrm{~kg}^{-1}\right)$, which explains higher levels of acid phosphatase activity. In accord to Mendes et al. (2012) the acid phosphatase activity is higher in natural vegetation, due to the conversion of organic phosphorus $\left(\mathrm{P}_{\mathrm{o}}\right)$ into inorganic phosphorus $\mathrm{P}_{\mathrm{i}}$. Carneiro et al. (2009) found a negative correlation between $\mathrm{Pi}$ level and acid phosphatase activity, which increases in the $\mathrm{P}_{\mathrm{i}}$ reduces the enzyme activity.

Table 3. Acid phosphatase and urease activities in Dystric Gleysol Paddy with different water management systems.

\begin{tabular}{ccc}
\hline & \multicolumn{2}{c}{ Enzyme activity } \\
\cline { 2 - 3 } Treatment & $\begin{array}{c}\text { Acid phosphatase } \\
\mathrm{mg} \text {-nitrophenol kg-1 }\end{array}$ & $\begin{array}{c}\text { Urease } \\
\mathrm{mg} \mathrm{NH}^{+} \mathrm{kg}^{-1} \mathrm{soil} \mathrm{h}^{-1}\end{array}$ \\
\hline M1 & $136.08 \mathrm{~b}^{*}$ & $2.91 *$ \\
M2 & $148.92 \mathrm{ab}^{*}$ & $3.18^{*}$ \\
M3 & $178.99 \mathrm{a}^{*}$ & $3.48^{*}$ \\
M4 & $158.35 \mathrm{ab}^{*}$ & $3.56^{*}$ \\
Mean & 155.59 & 3.28 \\
\hline CV\% & 17.18 & 24.84 \\
\hline MSD & 41.74 & - \\
\hline Control & 267.94 & 6.32 \\
\hline
\end{tabular}

Treatments: M1: Intermittent during entire cycle; M2: Intermittent/continuous; M3: Continuous/intermittent and M4: Continuous for entire cycle. Means followed by the same lowercase letter in the column did not differ statistcally by Tukey test $(p<0.05)$; MSD: Minimum significant difference between water managements, using the Tukey test. Means followed by an asterisk $(*)$ differ statisically from native vegetation by Kruskal Wallis test $(p<0.05)$.

There were no statistical differences among water management regarding urease activity (Table 3). Compared to the control, all treatments showed higher urease activity. An explanation to this finding is the higher SOC content in the control area, as well as higher microbial biomass. The urease activity is influenced by the presence of microorganisms and plant material composition (LANNA et al., 2010).
According to Nayak, Babu and Adhya (2007), increments in the organic matter and nitrogen content have a positive correlation with soil and enzymatic activity. The enzymatic activity patterns observed are a result of an oxidoreduction process during flooding, which may interfere with the soil microbial population, and the process influenced by biogeochemical processes (KÖGEL-KNABNER et 
al., 2010).

The principal component analysis (PCA) allowed for investigating the effect of water management system on soil and on rice varieties as shown in Figure 2. The variables acid phosphatase, SOC, N stock (Ns), and MBC showed better relationship with water management regimes and cultivar cropping when compared to the control.

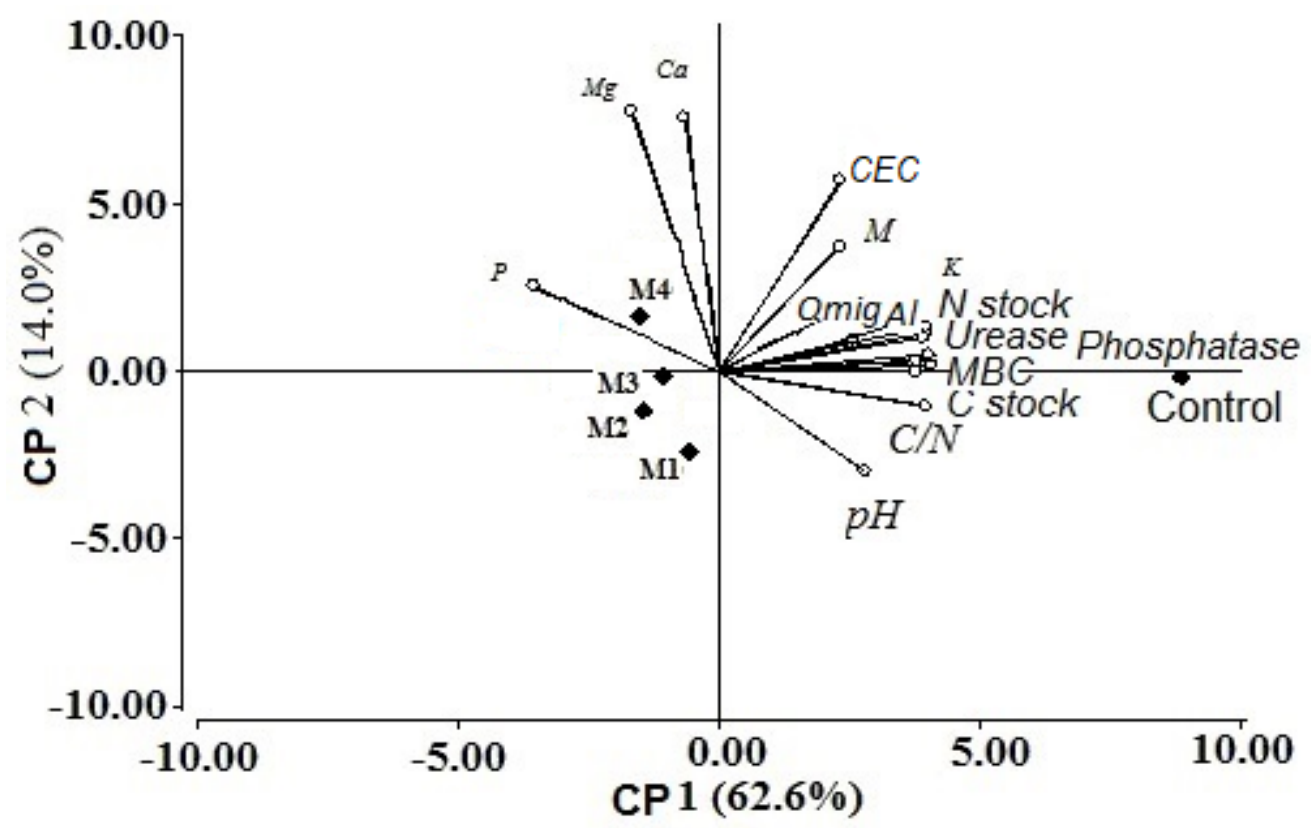

Figure 2. Ordination diagrams for chemical, physical, microbiological, and biochemical variables under different water management systems, two rice cultivars and the control.

According to the PCA, two groups were formed: PC1 and PC2 (Figure 2). The variables SOC (0.99), C (0.99), $\mathrm{H}^{+}(0.97), \mathrm{MCB}(0.97), \mathrm{N}(0.96)$, $\mathrm{C} / \mathrm{N}(0.96), \mathrm{K}^{+}(0.95)$, acid phosphatase $(0.92)$, urease $(0.92), \mathrm{pH}(0.68), \mathrm{TN}(0.56)$ from the watermanaged areas grown with rice cultivars showed higher variation when compared to the control (Figure 2). The results show that these indicators were the most sensitive to changes occurring in the soil under the flooding conditions grown with rice cultivars.

The characteristic that best reflects the changes that occurred in the soil was SOC. However, as observed in Figure 2, the variables $\mathrm{MBC}, \mathrm{K}^{+}$, urease and acid phosphatase also played an important role during soil reactions. The results found in the present study validate the data found by Li et al. (2013) and Liu et al. (2015) that emphasized the sensitivity of SOC as an indicator and stimulator of the microbiological and biochemical responses that occurred during the soil management.

The PC2 was formed by $\mathrm{Mg}^{2+}(0.89), \mathrm{Ca}^{2+}$ (0.87), and CEC (0.65), which were more strongly represented in the areas under water management than for the control. Phosphorus showed a negative correlation (-0.86) with $\mathrm{PC1}$ and a positive correlation with PC2 (0.26). The behavior of $\mathrm{P}$ within PC1 is due to the significant difference in nutrient concentrations between the cultivated areas as compared to the control.

The dendrogram generated from the variables (Figure 3), showed a significant difference in analysis of variance $(\mathrm{pH}, \mathrm{Ns}, \mathrm{TN}$ and acid phosphatase), grouping the most similar management regimes and cultivars.

As showed in the Figure 3, it was possible to form four groups: (1) the control, different from all others, (2) formed by M3, cultivars 1 and 2, and (3) by $\mathrm{M} 1$, with cultivar $\mathrm{C} 1$, and (4) formed by M4, cultivars $\mathrm{C} 1$ and $\mathrm{C} 2$, which are very similar, M2 and cultivar $\mathrm{C} 2$, which resembles M4 and $\mathrm{C} 1$ and $\mathrm{C} 2$, $\mathrm{M} 2, \mathrm{C} 1$ and M1and C1. The fourth group formed by the third group that only had the M1 and C2 as representatives. The reason why M1 was separated into different groups by cultivars can be explained by the significant interaction between the water management systems and with the cultivars. Using a dendrogram it was possible to confirm that the water management systems studied during rice cultivation promoted expressive changes on the evaluated soil characteristics when compared to the control. 


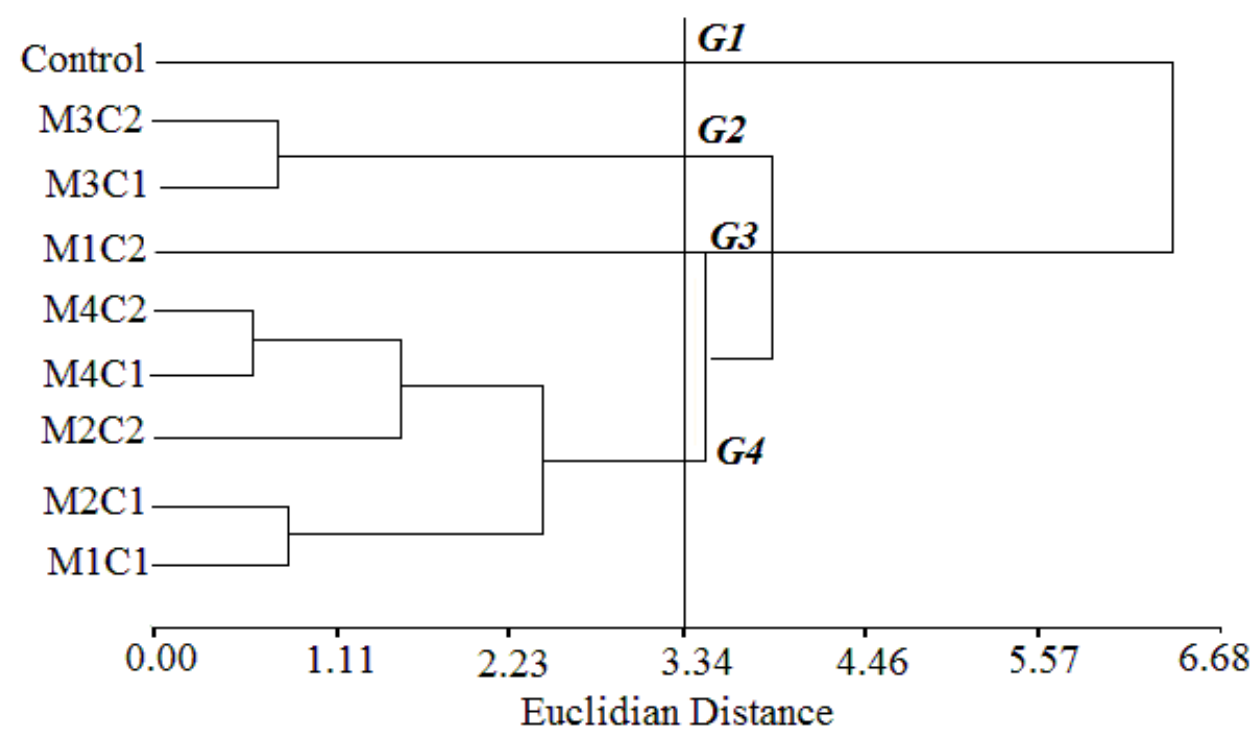

Figure 3. Dendrogram generated from grouping analysis for the studied variables from soil under different water management systems grown with rice cultivars and control.

There was a significant interaction for the carbon dioxide $\left(\mathrm{CO}_{2}\right)$ emissions flow between water management systems and data recording dates ( $p £ 0.05$ ). In contrast, $\mathrm{CO}_{2}$ flux for the control did not fit in any model (Figure 4). $\mathrm{CO}_{2}$ emission patterns were similar for M2 and M4 (Figure 4) that had the highest $\mathrm{CO}_{2}$ emissions during the sampling time. M1 and M3 $\mathrm{CO}_{2}$ emission patterns were also similar, and both had lower levels (Figure 4). Based on these findings, it can be inferred that intermittent flooding (M1) during the whole rice cycle and continuous flooding in the vegetative phase (M3) with intermittent irrigation in the reproductive phase, had a positive effect on the reduction of $\mathrm{CO}_{2}$ emissions. In Figure 4, the $\mathrm{CO}_{2}$ emissions were higher during the reproductive phase under intermittent flooding, equaling to continuous flooding treatment. However, this does not match the results of $\mathrm{Xu}$ et al. (2015) where lower $\mathrm{CO}_{2}$ efflux was observed in a rice paddy was under continuous flooding $\left(1.9 \mu \mathrm{mol} \mathrm{m}^{-2} \mathrm{~s}^{-1}\right)$.

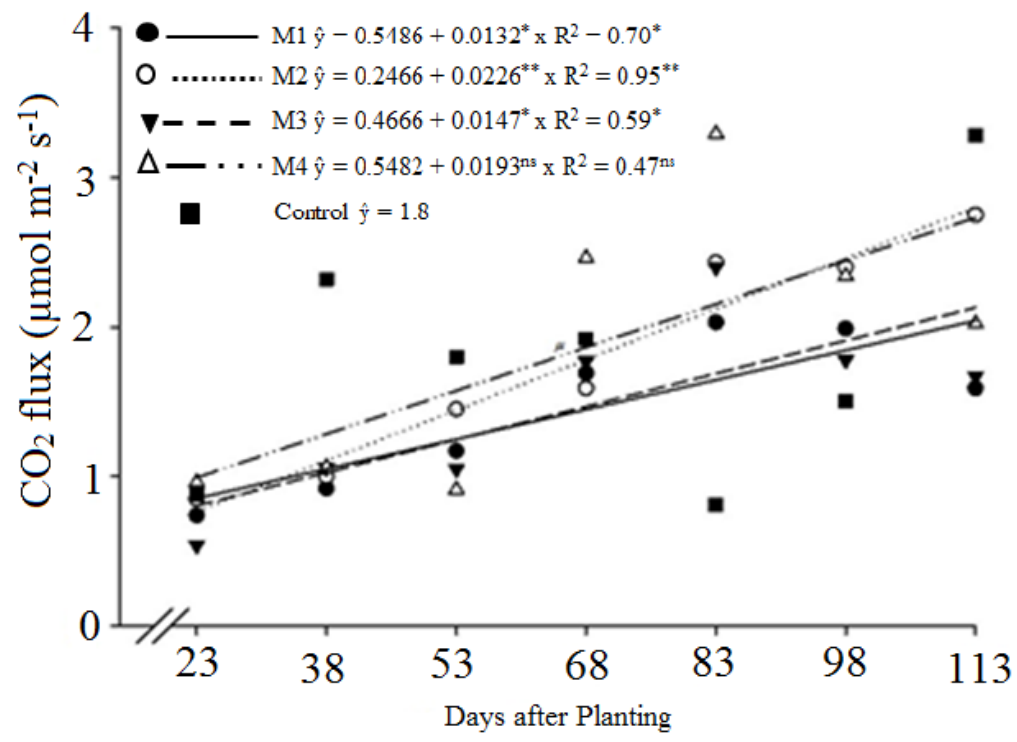

Figure 4. $\mathrm{CO}_{2}$ efflux from rice paddy field under different water management systems and from control. M1: intermittent during entire cycle; M2: Intermittent/continuous; M3: continuous/intermittent and M4: continuous for entire cycle. 
The $\mathrm{CO}_{2}$ levels showed increases over time, especially during the maturation phase for all the studied water management systems. An explanation for this result could be associated with the influence of the phenological stage of rice on $\mathrm{CO}_{2}$ efflux due to the different physiological demands. Flowering and subsequent grain maturation are the most energydemanding growth stages, as well as in reproductive phase, when the demand for nutrients and photoassimilates are higher than in the previous phases (UPHOFF, 2012). Consequently, during these high energy-demanding stages, the plant has a higher photosynthetic rate, resulting in greater nutrients absorption, increased respiration and which enhanced $\mathrm{CO}_{2}$ emission by the plant. Phenological stage and photosynthesis play an important role in $\mathrm{CO}_{2}$ flow, with the highest plant photosynthetic rates being correlated with the highest $\mathrm{CO}_{2}$ emissions (FLEXAS et al., 2012). According to Escobar et al. (2010), the $\mathrm{CO}_{2}$ flow in soybean increases during plant development, reaching its peak at flowering, and decreases at the subsequent reproductive phases.

\section{CONCLUSIONS}

Water management systems influences soil attributes at different intensities and alter the soil quality. The variables SOC, C-Stock, MBC, C/N ratio, $\mathrm{K}^{+}$, acid phosphatase and urease activities are the most sensitive attributes observed in the soil under different water management systems during rice cultivation.

$\mathrm{CO}_{2}$ emissions were influenced by water management systems, where the largest flows occurred in intermittent flooding and intermittent flooding in reproductive phase phase.

The $\mathrm{CO}_{2}$ emissions in the soil during rice growth are influenced by rice plant phenophase, where the major flux occurred during the reproductive phases.

\section{ACKNOWLEDGMENTS}

The authors would like to thank the CAPES (Brazilian Federal Agency for Support and Evaluation of Graduate Education and Project PróAmazônia).

We thank Dr. Richard Browning Jr, professor and Dr. Maria L. Leite-Browning, researcher, at Tennessee State University for reviewing and polishing in the English of this paper.

\section{REFERENCES}

BARBERENA, D. S.; MEDEIROS R. D.; BARBOSA, G. F. Desenvolvimento e produtividade de arroz irrigado em resposta a diferentes doses de fósforo e potássio, em várzea de primeiro ano, no estado de Roraima. Ciência Agrotecnologia, 35: 462-470, 2011.

CARNEIRO, M. A. C. et al. Atributos físicos, químicos e biológicos de solo de cerrado sob diferentes sistemas de uso e manejo. Revista Brasileira de Ciência do Solo, 33: 147-157, 2009.

CRUZ, C. D.; REGAZZI, A. J. Modelos biométricos aplicados ao melhoramento genético. 3 ed., Viçosa, MG. UFV, 1994. v. 2, 390 p.

DI RIENZO, J. A. et al. InfoGene versión 2013 Córdoba: Grupo InfoStat, FCA, Universidad Nacional de Córdoba. 2013.

ESCOBAR, L. F. et al. Postharvest nitrous oxide emissions from a subtropical oxisol as influenced by summer crop residues and their management. Revista Brasileira de Ciência do Solo, 34: 507-516, 2010 .

FAGERIA, N. K.; SANTOS, A. B. Resposta do arroz irrigado à adubação verde e química no Estado de Tocantins. Revista Brasileira de Engenharia Agricola e Ambiental, 11: 387-392, 2007.

FERREIRA, E. V. O. et al. Manganês na nutrição mineral de cultivares de arroz de terras altas. Pesquisa Agropecuária Tropical, 39: 151-157. 2009.

FERREIRA, D. F. Sisvar: a Guide for its Bootstrap procedures in multiple comparisons. Ciências e Agrotecnologia, 38: 109-112, 2014.

FLEXAS, J. et al. Mesophyll diffusion conductance to $\mathrm{CO}_{2}$ : An unappreciated central player in photosynthesis. Plant Science, 193: 70-84, 2012

JENKINSON, D.S.; POWLSON, D.S. The effects of biocidal treatments on metabolism in soil. A method for measuring soil biomass. Soil Biology \& Biochemistry, 8: 209-213, 1976.

KANDELER, E.; GERBER, H. Short-term assay of soil urease activity using colorimetric determination of ammonium. Biology and Fertility of Soils, 6: 68$72,1988$.

KNOBLAUCH, R. et al. Rice straw incorporated just before soil flooding increases acetic acid formation and decreases available nitrogen. Revista Brasileira de Ciência do Solo, 38: 177-184, 2014.

KÖGEL-KNABNER, I. et al. Biogeochemistry of paddy soils. Geoderma, 157: 1-14, 2010. 
LANNA, A. C. et al. Atividade de urease no solo com feijoeiro influenciada pela cobertura vegetal e sistemas de plantio. Revista Brasileira de Ciência do Solo, 34: 1933-1939, 2010

LI, P.et al. Development of biological soil quality indicator system for subtropical China. Soil and Tillage Research, 126: 112-118, 2013.

LIMA, A. C. R.; HOOGMOED, W. B.; BRUSSAARD, L. Soil quality assessment in rice production systems: establishing a minimum data set. Journal of Environmental Quality, 37: 623630, 2008.

LIMA, A. C. R. et al. Afunctional evaluation of three indicator sets for assessing soil quality. Apply Soil Ecology, 64: 194-200, 2013.

LIU, Z. et al. A simple evaluation of soil quality of waterlogged purple paddy soils with different productivities. PLoS ONE, 10: 1-16, 2015.

MARRENJO, G. J. et al. Impactos do cultivo por longo tempo de arroz inundado em Gleissolos. Pesquisa Agropecuaria Brasileira, 51: 967-977, 2016.

MENDES, I. C. et al. Biological functioning of Brazilian Cerrado soils under different vegetation types. Plant and Soil, 350: 183-185, 2012.

NAYAK, D. R.; BABU, Y. J.; ADHYA, T. K. Longterm application of compost influences microbial biomass and enzyme activities in a tropical Aeric Endoaquept planted to rice under flooded condition. Soil Biology and Biochemistry, 39: 1897-1906, 2007.

PEYRON, M. et al. Greenhouse gas emissions as affected by different water management practices in temperate rice paddies. Agricultural Ecosystem Environment, 232: 17-28, 2016.

RHODEN, A. C. et al., Mineralização anaeróbica em solos de várzea do Rio Grande do Sul. Ciência Rural, 36: 1780-1987, 2006.

SCHMIDT, F. et al. Impacto do manejo da água na toxidez por ferro no arroz irrigado por alagamento. Revista Brasileira de Ciência do Solo, 37: 12261235, 2013.

SIVA, F. C. Manual de análises químicas de solos, plantas e fertilizantes. 2 eds. Brasilia, DF: EMBRAPA, 2009. 627 p.

SLEUTEL, S. et al. Modeling soil moisture effects on Net Nitrogen Mineralization in Loamy Wetland Soils. Wetlands, 28: 724-734, 2008.

TABATABAI, M. A. Soil enzymes. In: WEAVER, R.W. et al. (Eds.). Methods of soil analysis: microbiological and biochemical properties. Part 2. Madison: Soil Science Society of America, 1994. Serie 5, p. 775-833.

TATE, K. R. et al. A direct extraction method to estimate soil microbial $\mathrm{C}$ : effects of experimental variables and some different calibration procedures. Soil Biology and Biochemistry, 20: 329-335, 1988.

TIAN, J. et al. Allocation and dynamics of assimilated carbon in rice-soil system depending on water management. Plant and Soil, 363: 273-285, 2013

UPHOFF, N. Supporting food security in the 21st century through resource-conserving increases in agricultural production. Agriculture and Food Security, 1: 1-12. 2012.

WEIL, R. R.; BRADY, N. C. The Nature and Properties of Soils. New York: Pearson Education. 2016. 1104 p.

$\mathrm{XU}, \mathrm{Y}$. et al. Effects of water-saving irrigation practices and drought resistant rice variety on greenhouse gas emissions from a no-till paddy in the central lowlands of China. Science of Total Environment, 505: 1043-1052, 2015. 